\title{
Paradigmatic Challenges in School Counselling: Correlates and Reflections on Practice
}

\author{
Halis Sakız ${ }^{1}$ and Mehmet Sarıçalı ${ }^{2}$ \\ ${ }^{1}$ Department of Psychology, Mardin Artuklu University, Mardin, Turkey and ${ }^{2}$ Department of Guidance and Psychological \\ Counselling, Nevşehir Hacı Bektaş Veli Üniversitesi, Nevşehir, Turkey \\ Address for correspondence: Halis Sakız, Campus Location, Faculty of Letters, 47100, Mardin, Turkey. Email: halissakiz@ \\ artuklu.edu.tr
}

(Received 02 August 2018; revised 24 September 2018; accepted 25 September 2018; first published online 30 October 2018)

\begin{abstract}
We examined the paradigmatic position of school counsellors as it relates to their practice. A survey and interviews were conducted with counsellors, counsellor educators, and teachers. Findings demonstrated that counsellors lacked skills regarding theoretical orientation and applications, counselling practices remained arbitrary and less effective due to the confusion experienced in the adaptation and application of counselling approaches, and the confusion in paradigms stemmed from problems in the identification of local needs, direct transfer of Eurocentric paradigms, training, and professional roles.
\end{abstract}

Keywords: paradigmatic position; school counselling; counselling practices; mixed methods; Turkey

The 21st century has brought about radical transformations in society with regard to social and personal values as well as social structures. While these changes create challenges for society at large, educational and school systems strive to keep up by making appropriate arrangements in their curricular organisations, pedagogical methodologies, and human resources. Along similar lines, while new principles and paradigms of school counselling are adopted, some others are transformed in ways that support professionals to organise and deliver appropriate counselling services. In a broad sense, for example, counselling ideology has evolved from a perspective of malady to non-reductionist and holistic perspectives (Hansen, 2017). Hence, today, school counselling systems are more concerned than yesterday with positive human development, educational equity, and social justice (Coleman \& Yeh, 2008).

Despite observable efforts to understand and respond to multiple aspects of educational and individual needs, the extent to which this mission has been achieved is questionable. Especially in countries where school counselling systems have not achieved an adequate level of maturation, major problems in the conceptualisation and implementation of counselling approaches and principles are still experienced (White \& Kelly, 2010). This study, therefore, embarks from the perspective of the lack of research regarding school counselling systems and aims to investigate the way counselling is theorised and practised in countries where there is an effort to develop effective counselling systems. The research was carried out in Turkey, a country that aims to improve its school counselling practice within the education system and searches for a professional identity of its own (Stockton \& Güneri, 2011). 


\section{Paradigmatic Stance in School Counselling}

The American Counselling Association (2010) defines counselling as a professional relationship that empowers diverse individuals, families and groups to accomplish mental health, wellness, education, and career goals. In order to achieve the aims of each practice in counselling, counsellors' competence plays a critical role. The idea of competence involves understanding and effective practice of theoretical knowledge that also includes paradigms in counselling. Therefore, the paradigmatic positioning of counsellors guides their practice and enhances their competence in setting a foundation on which the entire process of counselling is based. In this sense, paradigms function as a road map for action. Counsellors' decisions and choices regarding interventions, reactions, and analysis flow logically from a theoretical and paradigmatic model of what people are like, what is good for them, and what conditions are likely to influence them in a self-determined, desirable direction (Kottler \& Sheppard, 2008). Paradigms in counselling enable counsellors to deal with their clients' issues in a holistic and non-reductionist manner.

In many countries, including Turkey, the comprehensive developmental model has been adopted as the basis for mainstream school counselling programs (Dollarhide \& Saginak, 2012; Stockton \& Güneri, 2011). In order to support this model and establish comprehensive counselling programs, various human development theories have been applied (Paisley \& McMahon, 2001). As a result of the transition towards a comprehensive developmental model, services became more developmental and preventative in focus, supporting all individuals to self-actualise and achieve mastery of appropriate developmental tasks (Green \& Keys, 2001). In addition, as we approached the 21st century, comprehensive developmental counselling programs started to be conceptualised around principles of multiculturalism and positive development for all children. In practice, this means that schools and counsellors need to apply intersectional approaches, challenge oppressive institutional forces, and meet the needs of a diverse student population (Moradi \& Grzanka, 2017).

Theoretical positioning in counselling is related to various factors such as training of counsellors, the level of support they receive, and the effectiveness of the services they offer. Over the last few decades, we have witnessed the development of international and national criteria that have prompted school counselling systems to achieve higher levels of what students should now be able to do. Since that time, a stronger argument has been developed as to whether school counselling services can produce meaningful, accountable and evidence-based outcomes (Sink, 2009; Whiston, Tai, Rahardja, \& Eder, 2011). Setting higher expectations would necessitate the development of new and different measures of accountability to evidence that student competencies — and ultimately, the standards - are achieved. Therefore, school counsellors would have a common agenda to perform activities that have a positive impact on student achievement, social-emotional skills, and effective career planning while they provide evidence of what the services they provided have achieved (Hatunoglu, 2017).

Structural issues can disrupt the development of effective school counselling systems. For example, the need for a clear mission and role definition is one of the most encountered requirements in many counselling systems (Sakız et al., 2015). Various interpretations of the role of school counsellors against rapidly changing social, economic and political conditions as well as the consequent challenges posed by these changes can mean role conflict for school counsellors (Gysbers, 2001). Another commonly experienced problem is infrastructural inadequacies such as overpopulation and limited material and human resources. These challenges make it difficult to create a school atmosphere where counsellors can develop effective services (Casey-Cannon, 2008).

While dealing with structural problems, school counsellors on the one hand and stakeholders in developing countries on the other hand need to develop effective school counselling systems based on sound theoretical frameworks that overlap with the local realities of their regional and cultural systems. This is demanding, considering the fact that school counselling systems in many developing countries are a direct and unsuccessful transfer of some Western counselling approaches (Dogan, 2000; Korkut, 2007; Mocan-Aydin, 2000; Stockton \& Güneri, 2011). For example, while some counsellors 
are aware of developmental, holistic and multicultural approaches, many interventions focus only on the client by overlooking the systemic and contextual factors (Sakız et al., 2015).

\section{School Counselling in Turkey}

In Turkey, the counselling profession has a history of approximately seven decades. The pioneers of the counselling field in Turkey are generally oriented with humanism, leading to the dominance of this approach in the field (Mocan-Aydin, 2000). In addition, some other approaches, such as Ellis' approach to rational emotive therapy (Dogan, 2000) and reality theory (Mocan-Aydin, 2000), were suggested as good options to apply in the field. In addition, there has been an emphasis on the preventative and developmental approaches in counselling in recent years (Korkut, 2007; Stockton \& Güneri, 2011). However, considering structural and practical outcomes as well as cultural realities, there are question marks as to how functional the direct application of these approaches has been in education and other settings. For example, question marks still exist as to whether several counselling paradigms are appropriate to local contexts.

Counselling education in Turkey is a teaching program and embedded within the curriculum of educational sciences as part of education faculties. Education is provided at the undergraduate and graduate levels under the programs named Guidance and Psychological Counselling and Counselling Services in Education. Completing the undergraduate level provides the necessary qualification for working as a counsellor. The main purpose of the undergraduate counsellor education is to equip students with basic counselling skills and prepare them for professional life (Aladag \& Bektas, 2009). After graduation from the undergraduate degree, the vast majority of counsellors start working in schools at primary and secondary levels. Masters' and doctoral programs are preferred for an academic career or personal development.

The number of counselling education programs has rapidly increased in the last 15 years in Turkey. This period of explosive growth has occurred along with the discussion of the need to shift from a competence paradigm based on quantitative growth (Arslan \& Sommers-Flanagan, 2018). However, structural problems still exist within the profession. Despite an increase in the number of counsellors and schools, counsellors still have to serve a large population of students. Another problem is the confusion regarding the purpose, roles, and functions of counsellors (Stockton \& Güneri, 2011; Öner, 1994). A study conducted by Sakız, Sarıcalı, and Türküm (2017) demonstrated that undergraduate education was inadequate for providing counsellors with adequate counselling and supervision skills. Moreover, undergraduate counselling education programs vary significantly in terms of content and quality. Internship program opportunities and the systematic supervision of counsellors in training at the undergraduate level are not adequate (Aladağ \& Kemer, 2016).

All in all, in many countries where school counselling is in a process of maturation, there is confusion among decision-makers and school counsellors regarding the understanding on which the mission, orientation, and implementation will be based. Looking at the current gap in research that investigates this phenomenon, such research is urgently needed. Obtaining data from multiple sources, we believe that this research can contribute to the establishment and reform of the school counselling system in developing countries. Therefore, according to the parameters described above, this research aims to respond to the following research questions: (1) What is the role of counselling paradigms in the practice of school counsellors? (2) Which factors influence school counsellors' means of effective service delivery?

\section{Method}

As a guiding research paradigm, a mixed-methods design was used in this research. Mixed-methods research describes the acquisition, analysis, and integration of quantitative and qualitative data in a single or multiphase study and enables researchers to collect rich data from multiple perspectives 
and paradigms (Creswell, Plano Clark, Gutmann, \& Hanson, 2003). In this research, attributes of school counselling in Turkey were described through a survey while interviews enabled researchers to collect details of these attributes.

\section{Participants}

Two hundred and ninety-two school counsellors, 36 counsellor educators and 188 teachers participated in this study. All participants worked in public schools and universities in Turkey. The counsellors and teachers worked in primary ( $n=105$ and 76 respectively), pre-secondary ( $n=83$ and 54 respectively), and secondary schools ( $n=104$ and 58 respectively) while all counsellor educators worked in universities. Teachers belonged to eight branches: class teaching $(n=58)$, Turkish language teaching $(n=34)$, mathematics teaching $(n=24)$, science teaching $(n=23)$, social science teaching $(n=19)$, English language teaching $(n=17)$, religious culture and moral teaching $(n=10)$, and special education $(n=3)$. The counsellor educators worked in the departments of guidance and psychological counselling and psychological services in education. The mean age for all participants was 40.8 while it was 34.6 for counsellors, 47.6 for counsellor educators, and 40.2 for teachers. The years of experience ranged from 1 to 21 for counsellors, 6 to 32 for counsellor educators, and one to 24 for teachers.

Several sampling strategies were used in order to employ participants for this study. All counsellors and teachers worked in schools located in 12 and nine different cities, respectively. One hundred and three school counsellors and 112 teachers who were known to the researchers were recruited purposively via personal visits and personal messages through social media. Another 189 counsellors and 85 teachers were randomly recruited via social media. All counsellor educators were randomly selected from academics and contacted via email or telephone. Following survey administration, all participants were asked whether they would volunteer for a follow-up interview through an option within the survey. Twenty-six counsellors, 6 counsellor educators, and 16 teachers selected this option and volunteered to participate in an interview.

\section{Data Collection Instruments}

A survey and interviews were the main data collection methods used in this study. The survey comprised 11 questions with a Likert-type scale of 3 points (inadequate, neither adequate nor inadequate, and adequate) that was prepared by the researchers based on relevant international and national literature and policy (e.g., Coleman \& Yeh, 2008; Green \& Keys, 2001; Ministry of National Education, 2001; Sakız et al., 2015). The survey was constructed as a descriptive design by theme (Coles \& McGrath, 2010), which means that it did not seek to test any statistical hypotheses and did not require psychometric analysis. Questions that were related to the research aims were constructed and grouped together according to the issues they explored. Three experts in the field were provided with the research questions and asked to provide feedback about the quality of the survey. Finally, corrections were made following their feedback.

The questions in the survey were inclusive of the three participant groups: counsellors, counsellor educators, and teachers. The questions aimed to collect participants' views regarding the level of theoretical and practical competence of counsellors, as well as the effectiveness of the services they provide, the role of training in this competence, and the role of systemic factors in this competence.

A specific set of interview questions was developed for this study. The questions focused on the role of counselling paradigms in school counsellors' practice and issues experienced in the schools that influenced the counsellors' service. The schedules included open-ended questions (e.g., 'How do you develop and employ an approach appropriate to your clients' needs?' and 'What do you think about the meaningfulness of the outcomes you achieve in relation to your clients' needs?'). The questions were prepared in line with the research aims and varied in content according to the participants' profession. 
Development of the questions followed these guidelines: (a) questions should be equivalent in relevance for all three participant groups, (b) questions should represent meaning for counsellors working in public schools in Turkey, (c) questions should present a degree of criticality likely to elicit responses, (d) leading questions that suggest attributions should be avoided, (e) open-ended questions should be followed by narrower prompts to elicit specific responses. A pilot version of the questions was administered to four counsellors, one counsellor educator, and three teachers. Pilot materials were presented in Turkish. Pilot subjects reviewed the questions, responded to them and were interviewed for 30-40 minutes to elaborate on their responses and provide feedback about the materials. The pilot study results were used by a panel of three counselling experts. Because the participants in the pilot study required considerably more than one hour to finish, we decided to reduce the number of questions to 11. These questions were those rated by the experts as the least ambiguous, most relevant and salient, and most likely to elicit more responses.

\section{Data Collection}

Prior to data collection, we obtained ethical permission from the ethical board of the related academic institution and informed consent from each participant. The mixed-methods sequential explanatory design involved two distinct phases: a quantitative phase followed by a qualitative one (Creswell et al., 2003). The rationale for this approach was that the quantitative data and its subsequent analysis provided a general understanding of the research problem while the qualitative data and its analysis refined and explained those statistical results by exploring participants' views in more depth (Creswell et al., 2003).

Online and traditional paper-pencil methods were used in for filling in surveys. The online version was created via Google Forms. In the online data collection process, we used social media groups and virtual communication networks where only school counsellors or only teachers were involved. Counsellor educators were contacted first via institutional emails. Hard copies of the survey were given to participants, who were contacted face to face. In the first cycle, all participants were asked to fill in the survey. For the interviews, counsellors and counsellor educators who participated in the survey were invited. Twenty-seven interviews were conducted face to face while 21 interviews were conducted via telephone or Skype. The purpose of the research was briefly introduced to all participants. Consent forms introducing the research process, including confidentiality and volunteerism, were sent to all participants. Interviews lasted between 24 to 45 minutes.

\section{Data Analysis}

There were two types of data analysis. First, survey data were analysed quantitatively by means of descriptive statistics, revealing frequencies and percentages for each survey question. These findings were presented for participant groups of counsellors, counsellor educators, and teachers.

For the analysis of qualitative data, a consensual, qualitative research method was adopted (Hill, Thompson, \& Williams, 1997). In this method, first, we continuously cycled through the data, made comparisons between the data and the derived categories until the core ideas had been verified. Second, we used auditors to arrive at consensus judgments and check all the work. Third, we coded the data initially into rationally derived domains and then abstracted the core ideas. Fourth, we compared the data systematically across cases and tabulated the number of cases that fit within each category. Finally, findings across domains which may or may not have been sequential were described.

Teams of coders included members of the research team, involving two researchers who were previously school counsellors and two research assistants working in the field of counselling. The coding process involved decision making by consensus. The first researcher was a postdoctoral faculty member and the second was a graduate researcher completing a doctorate degree. First, the interviews were read by research assistants who offered their impressions of the comparisons. 
Answers written in Turkish were translated independently by the assistants to ensure translation equivalence and reliability. Differences in translation were resolved through consensus. Second, researchers and assistants worked individually to assign domains to patterns in the data, based on a previously prepared list of domains. While developing preliminary coding categories for the written data, team members suggested improvements and revisions to increase accurate understanding and completeness of the coding categories. Next, team members gathered to draw from them a smaller number of higher order core ideas and overarching categories that reflected dominant themes within the data. Throughout the final analysis, this peer debriefing continued to validate primary themes. In the last phase, an audit trail was kept throughout the process (Denzin \& Lincoln, 2005). The audit trail consisted of the raw data, the field notes and coding memos, notes on data reduction and analysis, selected audiotapes of data analyses, team discussions, and peer debriefing notes.

\section{Findings}

Findings are presented in this section such that numerical and textual data are combined under each theme. Table 1 includes the findings of the survey administered to counsellors, counsellor educators, and teachers.

\section{Lack of a Route, Arbitrary Practice and Ineffective Outcomes}

All participants in the study were asked to provide their opinions regarding the role of counselling theories and approaches in their practice. Participants' responses regarding counsellors' competence in using counselling theories and approaches were far from being universally adequate or inadequate. However, the ratio of participants perceiving counsellors as inadequate was striking: fewer than half the counsellors (41.8\%), counsellor educators (33.3\%), and teachers (30.9\%) thought that counsellors possessed an adequate level of competence in employing counselling theories and approaches. A counsellor educator illustrated this by saying: 'There is a superficial and descriptive way of teaching theories and approaches. As a result, counsellors rarely gain insight and take significant actions.'

Providing effective counselling services requires careful evaluation and conceptualisation of clients' needs in line with their personal and cultural patterns. Slightly more than half the counsellors (57.9\%) and counsellor educators (52.8\%), and less than half the teachers (43.6\%) thought that counsellors could achieve this task. Similarly, less than half the counsellors (48.6\%), counsellor educators (25.0\%), and teachers (14.9\%) thought that counsellors could employ approaches that enabled provision of services contributing to the development and learning of their students. This thinking was in line with the following teacher's statement: 'In schools where I worked, counsellors' best practice was to advise short-term solutions, such as talking with students for ten or fifteen minutes. However, nothing would change. Most counsellors' practice is arbitrary.' These statements support the notion that when clients' needs are not identified along with local realities, counsellors are less likely to employ appropriate approaches and take significant actions.

When it comes to using counselling theories and approaches to reach all students, less than half the counsellor educators (47.2\%) and teachers (36.2\%), and slightly more than half the counsellors (56.2\%) thought that counsellors could carry out this task. For example, a teacher said: 'Counsellors apply the same approaches and methods to all children as if the needs of all are the same.' Counsellors' skills in reaching students with diverse characteristics such as migrants or those with disabilities were also evaluated. Less than half the counsellor educators (44.4\%) and teachers (41.5\%), and the majority of counsellors (64.4\%) thought that counsellors possessed adequate skills. A counsellor who thought more favourably of this said: 'I try to understand the case of each individual and develop an appropriate approach.' In contrast, a counsellor educator said: 'The education system prefers the most able students at the expense of those with low ability levels. The case in counselling is the same.' 
Table 1. Descriptive Statistics Regarding Participant Responses to Survey Questions

\begin{tabular}{|c|c|c|c|c|c|c|c|c|c|}
\hline \multirow[b]{3}{*}{ Questions } & \multicolumn{3}{|c|}{ Inadequate } & \multirow{2}{*}{\multicolumn{3}{|c|}{$\begin{array}{c}\text { Neither adequate nor } \\
\text { inadequate }(F) / \%\end{array}$}} & \multicolumn{3}{|c|}{ Adequate } \\
\hline & \multicolumn{3}{|c|}{$(F) / \%$} & & & & \multicolumn{3}{|c|}{$(F) / \%$} \\
\hline & $C$ & CE & $T$ & $C$ & $\mathrm{CE}$ & $T$ & $C$ & CE & $T$ \\
\hline $\begin{array}{l}\text { How do you evaluate your/counsellors' level of professional } \\
\text { competence? }\end{array}$ & $(46) / 15.8$ & (9)/25.0 & $(91) / 48.4$ & $(68) / 23.3$ & $(17) / 47.2$ & $(51) / 27.1$ & $(178) / 61.0$ & $(10) / 27.8$ & $(46) / 24.5$ \\
\hline $\begin{array}{l}\text { How do you evaluate the overall effectiveness of the counselling } \\
\text { services you/counsellors provide? }\end{array}$ & $(51) / 17.5$ & $(7) / 19.4$ & $(102) / 54.3$ & $(49) / 16.8$ & $(9) / 25.0$ & $(18) / 9.6$ & $(192) / 65.8$ & $(10) / 27.8$ & $(47) / 25.0$ \\
\hline $\begin{array}{l}\text { How do you evaluate adequacy of your/counsellors' bachelor training } \\
\text { to enable meeting the needs of counselees? }\end{array}$ & $(82) / 28.1$ & $(11) / 30.6$ & (83)/44.1 & $(57) / 19.5$ & (3)/8.3 & $(51) / 27.1$ & $(153) / 52.4$ & $(22) / 61.1$ & $(54) / 28.7$ \\
\hline $\begin{array}{l}\text { How do you evaluate the contribution of the way counselling services } \\
\text { are organised within schools to your/counsellors' effectiveness? }\end{array}$ & $(104) / 35.6$ & $(16) / 44.4$ & $(38) / 20.2$ & $(74) / 25.3$ & $(4) / 11.1$ & (19)/10.1 & $(114) / 39.0$ & $(16) / 44.4$ & $(131) / 69.7$ \\
\hline $\begin{array}{l}\text { How do you evaluate the level of collaboration between counsellors, } \\
\text { teachers, families and school managers? }\end{array}$ & $(148) / 50.7$ & $(21) / 58.3$ & $(99) / 52.7$ & $(47) / 16.1$ & $(6) / 16.7$ & $(17) / 9.0$ & $(97) / 33.2$ & (9)/25.0 & $(72) / 38.3$ \\
\hline $\begin{array}{l}\text { How do you evaluate the contribution of the theoretical knowledge and } \\
\text { background you/counsellors' obtained during bachelor training to } \\
\text { enable meeting the needs of counselees? }\end{array}$ & $(126) / 43.2$ & $(13) / 36.1$ & $(84) / 44.7$ & $(51) / 17.5$ & $(6) / 16.7$ & $(38) / 20.2$ & $(115) / 39.4$ & $(17) / 47.2$ & $(66) / 35.1$ \\
\hline $\begin{array}{l}\text { How do you evaluate your/counsellors' competence in employing } \\
\text { counselling theories and approaches effectively? }\end{array}$ & $(109) / 37.3$ & $(14) / 38.9$ & $(69) / 36.7$ & $(61) / 20.9$ & $(10) / 27.8$ & $(61) / 32.4$ & $(122) / 41.8$ & $(12) / 33.3$ & $(58) / 30.9$ \\
\hline $\begin{array}{l}\text { How do you evaluate your/counsellors' competence in conceptualising } \\
\text { counselees' needs in line with their personal and cultural patterns? }\end{array}$ & $(48) / 16.4$ & $(8) / 22.2$ & $(65) / 34.6$ & $(75) / 25.9$ & $(9) / 25.0$ & $(41) / 21.8$ & $(169) / 57.9$ & $(19) / 52.8$ & $(82) / 43.6$ \\
\hline $\begin{array}{l}\text { How do you evaluate your/counsellors' competence in employing } \\
\text { approaches that enable providing services that contribute to } \\
\text { development and learning of students with diverse backgrounds } \\
\text { (ability level, ethnicity etc.)? }\end{array}$ & $(59) / 20.2$ & $(14) / 38.9$ & $(51) / 27.1$ & $(45) / 15.4$ & $(6) / 16.7$ & $(59) / 31.4$ & $(188) / 64.4$ & $(16) / 44.4$ & $(78) / 41.5$ \\
\hline $\begin{array}{l}\text { How do you evaluate your/counsellors' competence in employing } \\
\text { approaches that enable providing services that contribute to } \\
\text { students' development and learning? }\end{array}$ & $(96) / 32.9$ & $(22) / 61.1$ & $(122) / 64.9$ & $(54) / 18.5$ & (5)/13.9 & $(38) / 20.2$ & $(142) / 48.6$ & $(9) / 25.0$ & $(28) / 14.9$ \\
\hline $\begin{array}{l}\text { How do you evaluate your/counsellors' competence in employing a } \\
\text { variety of approaches that enable reaching all students? }\end{array}$ & $(77) / 26.4$ & $(11) / 30.6$ & $(79) / 42.0$ & $(51) / 17.5$ & $(8) / 22.2$ & $(41) / 21.8$ & $(164) / 56.2$ & $(17) / 47.2$ & $(68) / 36.2$ \\
\hline
\end{tabular}

Note: $\mathrm{CE}=$ counsellor educators, $\mathrm{C}=$ counsellors, $\mathrm{T}=$ teachers. 
To summarise, while some counsellors illustrated the good use of counselling theories and approaches, a significant number of participants agreed that counsellors had difficulties in using theories and approaches for conceptualising a problem, establishing integrity between understanding, interpretation and action, and producing effective outcomes.

\section{Counsellor Competence, Training, and Role Identification}

Participants' responses demonstrated that the level of success achieved in the school counselling system was related to the way counsellors were trained and accredited. There were mixed results, with a high ratio of dissatisfaction with counsellor training and accreditation, especially when it came to acquiring a sound theoretical background, employing effective practices, and achieving meaningful outcomes. For example, less than one quarter of the teachers $(24.5 \%, 25.0 \%)$ and slightly more than one quarter of the counsellor educators $(27.8 \%, 27.8 \%)$ thought that counsellors had an adequate level of competence and that their practices were effective, respectively. As for counsellors, a considerable portion of them thought that their levels of competence and effectiveness were inadequate $(15.8 \%$, $17.5 \%)$ or neither adequate nor inadequate $(23.3 \%, 16.8 \%)$.

The levels of competence and effectiveness were related to how counsellors were trained at universities. Findings indicated that counsellor training did not merge counselling practice with the reality of the field. Slightly more than half the counsellors (52.4\%) and counsellor educators (61.1\%), and one quarter of the teachers $(28.7 \%)$ thought that the undergraduate education enabled counsellors to meet the needs of clients. For example, a counsellor educator said: 'A superficial and general counselling education is given at the undergraduate level. However, specialisation at the graduate level must be required before entering the field.' A counsellor added: 'The content of the counsellor education does not enable effective practice in schools. The internship program is very superficial and far from the realities of school counselling.'

When it came to equipping counsellors with a sound theoretical knowledge and background, less than half the counsellors (39.4\%), counsellor educators (47.2\%), and teachers (35.1\%) thought that the undergraduate education was adequate. For example, a counsellor said: 'We learn simple communication skills and we are taught client-centred and humanistic approaches with no reference to practice. I did not feel adequate when I graduated.' A counsellor educator also reported a negative statement: 'In reality, school counsellors are raised as pedagogues or teachers. There is a big problem here. In this case, you may not clarify your role and make it visible and viable.'

Another finding revealed that counsellor education programs included content directly transferred from Eurocentric ideologies and theories. Despite the significance of acquiring knowledge of major theories such as psychoanalytic and developmental approaches, training needed to centre on how these could be implemented within the context of individual needs and local realities. A counsellor gave an example: 'We did not learn how to convert theory into practice because there were not enough case studies. We became counsellors with no real counselling practice. The only opportunity for practice was school visits for a few weeks. We were just observers there.'

Turning the skills and theoretical background into effective practice requires that counsellors' professional roles are clearly identified and that they are kept accountable for these roles. However, significant problems were expressed by participants. First, a counsellor educator mentioned the general accreditation problem in the counselling profession in Turkey: 'You see fake counsellors with no counselling training. Some of them are on TV.' A teacher also said: 'We do not know what counsellors should do. I do not think their job is to wait in the office and call students for individual meetings.' A counsellor illustrated the other side of the coin: 'Your title in the school is a teacher, not a counsellor. However, you are not in the classroom. In a crisis situation, the principal wants you to provide a quick decision. Although school counsellors are not professionally recognised and respected by the school administration as counsellors, during critical periods, the decision-making responsibility is left to them.' 


\section{Support, Collaboration, and Structures}

The means of converting the theoretical and practical backgrounds to effective practices are linked to how counselling structures are designed and supported in schools. Findings indicated that counsellors did not receive adequate managerial support and faced issues such as student overpopulation and lack of human and material resources. In this study, less than half the counsellors (39.0\%) and counsellor educators (44.4\%) thought that the way services were organised within schools was related to the effectiveness of these services. The majority of teachers $(69.7 \%)$ thought that school structures were adequate for effective service delivery. For example, a teacher said: 'Counsellors have time, room, and flexibility. However, their knowledge and practice is not adequate.' A counsellor, on the other hand, stated: 'Neither managers nor teachers know the details of our job so we have to do everything on our own. The number of students is high and we continuously deal with paperwork.'

Stakeholders within the system should collaborate to achieve effective counselling services. However, only a minority of counsellors (33.2\%), counsellor educators (25.0\%), and teachers (38.3\%) believed that the level of collaboration between counsellors, teachers, families, and school managers was adequate. A counsellor said: 'Common purposes should be identified and shared by everyone. Consider that you work with children to enhance their engagement level but their teachers ignore them in class just because they cannot do well in examinations.'

\section{Knowledge and Practice of Contemporary Paradigms}

In this study, findings revealed that obsession with some educational paradigms such as ableism and inequity prevented school counsellors from setting guidelines, conceptualising problems or situations, and developing appropriate actions. Some participants believed that schools were for the most able students. For example, a counsellor said: 'We focus on projects that target achievement in examinations and prioritise students with a capacity to achieve a degree in these examinations.' Another counsellor said: 'We had two students with symptoms of autism. They needed evaluation, individual support, and family counselling but their parents rejected this because this could place their academic achievement at risk.' Both statements illustrate the lack of an approach targeting development for all students and focusing on their needs.

Findings in this study showed that clinging to an individual paradigm led to overlooking the role of various factors in the system surrounding individuals. For example, a teacher said: 'I never send my students [to counsellors] because they [counsellors] only think students are things to get fixed. Instead, I focus on families because I know there is a problem not related to students.' Sometimes, counsellors were unaware of the reality that societies were becoming increasingly diverse. For example, a counsellor said: 'It is a mistake that refugees are sent to mainstream schools instead of segregated schools where they should be educated with their refugee peers. Resources are not enough to even local students.' These statements show that counsellors lacked understanding of inclusive, multicultural, and holistic paradigms in counselling.

\section{Discussion}

The aim of this study was to investigate the paradigmatic position of school counsellors as it related to their practice in schools. Findings revealed mixed beliefs regarding counsellors' adequacy, with a considerable number of counsellors, counsellor educators, and teachers thinking that counsellors needed to improve their theoretical orientation and practice. In addition, counsellors experienced difficulties in basing their thinking and practice on appropriate paradigms that fit the needs, educational preferences and social priorities of their students. Next, counselling practices were arbitrary and not effective, mostly due to the problems experienced in the adaptation and application of counselling theories and approaches. Finally, the paradigmatic challenges mostly stemmed from 
issues experienced in the identification of local needs, direct transfer of foreign thoughts, professional training, identification of professional roles, accountability, and standards.

In this study, counsellors had difficulties in finding a route that could provide them with working guidelines, enable them to locate which areas to work on, and help them make a professional evaluation of their progress. According to Boy and Pine (1983), an appropriate theoretical orientation guides counsellors to support clients in the successful change of their cognitions, interpersonal relationships, behaviour, and emotional functioning. It also guides counsellors on their evaluation of both the previous and latest approaches used in their counselling sessions. Without guidelines specific to each case, it becomes difficult for counsellors to have a consistent framework through which they view clients' issues and help them address it in the most efficient way.

Findings indicated that challenges in implementing appropriate counselling approaches were associated with arbitrary practice and ineffective outcomes. There were reports of good evidence-based practices; however, these were mostly found in individual cases and were not representative of the entire counselling service. In fact, results of a meta-analysis related to the effectiveness of school counselling yielded the finding that school counselling activities and interventions varied in effectiveness (Whiston et al., 2011). In that sense, approaches oriented to each case and tied with evidence-based practice may be associated with effective functioning in school counselling (Sink, 2009). However, this requires the acquisition of counselling approaches through insight, and reflecting this insight through action. A sound paradigmatic position provides the counsellor with a lens to look through the whole counselling process, the signs of the needs of the clients, and methods to promote clients' improvement (Kottler \& Sheppard, 2008).

Findings indicated that counsellors' competence in terms of theoretical orientation and practice was related to the undergraduate counsellor training. Looking at the content of the counselling education programs in Turkey, one can see that the majority of the content is filled by skills education and pedagogical theories. A study conducted by Sakız et al. (2017) demonstrated that counselling programs in Turkey varied significantly in terms of content and quality. In addition, the undergraduate education was inadequate in providing counsellors with conceptual (e.g., theoretical knowledge and expertise) and practical (e.g., working with diversity, collaboration) counselling skills that would enable them to produce effective outcomes in terms of student learning and development as well as professional improvement. Founded on a model that includes comprehensive development and social justice, the undergraduate education should provide counsellors with insight, a philosophical grounding, and opportunities to recognise and practice approaches that focus on action (Ravi, 2010).

Participants in this study thought that the counsellor education lacked sufficient opportunities for developing expertise in theoretical orientations and practical competence. In findings of previous research conducted in Turkey, the reasons for this situation were the insufficiency and inadequacy of the undergraduate education for the development of one's practice as a counsellor (Yeşilyaprak, 2009), the potential conflict between indigenous cultural structures and counselling backgrounds directly transferred from Western approaches (Mocan-Aydin, 2000; Stockton \& Güneri, 2011), and the lack of school counselling curricula that focused on contemporary approaches and contained an adequate practical aspect (Kagnici, 2014). Similarly, research conducted internationally highlighted the need for content-specific courses and practices that could be used by counsellors working in urban, suburban and rural areas at different levels of schooling (Hannon, 2016; Perusse \& Goodnough, 2005).

In this study, we found that problems in role identification, accountability, managerial support, collaboration, and school infrastructure prevented counsellors from organising and managing counselling processes effectively. Actually, similar problems were experienced around the world. For example, there were inconsistencies and confusion in counsellors' roles (Dahir, 2004; Gysbers, 2002; Johnson, Nelson, \& Henriksen, 2011), differences in counsellor-principal priorities and perceptions (Dahir, Burnham, Stone, \& Cobb, 2010), and inconsistent expectations of students, parents, and administrators from counsellors (Natividad, 2010). To solve these problems, official guidelines for 
accreditation and role definition should be set and school structures in which counsellors feel supported and motivated should be established (Doğan, 2000; Ender, Saricali, Satici, \& Eraslan-Capan, 2018; Stockton \& Güneri, 2011).

Findings indicated that counsellors lacked the knowledge and practice of contemporary paradigms and thoughts in counselling. The changing needs of individuals and society, the competitiveness of education systems, the multicultural world, and the multidimensional nature of problems and situations require counsellors to acquire knowledge of paradigms involving human development, systems approaches, multiculturalism, inclusion, and equity (Keklik, 2010; Slaten \& Baskin, 2014). However, we found that the counselling education programs lacked content related to social justice and skill development to challenge contextual barriers. In fact, the counselling literature shows that counsellors need to possess multicultural competence and awareness and therefore take an active role in the formation of social justice (Gonzalez, 2012). Actually, this theme coincides with the transformative leader roles of counsellors (Fassinger, Buki, \& Shullman, 2017) and the role of advocating social justice (Bemak \& Chung, 2011; Chang, Crethar, \& Ratts, 2010; McMahon, Mason, \& Paisley, 2009; Stone-Johnson, 2015).

\section{Limitations and Conclusion}

This study had some limitations that can be targeted by future research. First, only the perspectives of professionals were collected while other stakeholders such as students, parents and school managers were not included in the study. Although the technical aspects in this study (e.g., theory use) required professional opinions, issues such as the effectiveness of counselling practices could also be explored from the perspectives of students and parents. Second, the qualitative aspect of the study meant that we relied on the statements of participants and made conclusions based on these. However, future studies may attempt first-hand data collection techniques, such as working documents regarding counselling services or direct and longitudinal observation. Third, interview participants were recruited from survey participants, and therefore the consistency between their responses in both data collection procedures could not be controlled.

To conclude, this study presented the paradigmatic challenges experienced by school counsellors and how their practice was influenced by these challenges. Although data were specific to professionals working in Turkey, findings may present opportunities for professionals going through similar developmental processes in other countries to analyse their own situations. Although findings were mixed and contained considerable negative perceptions, they promise better outcomes for the future if: (a) counselling education programs analyse and reflect the needs of society, the trends of the counselling profession, and the priorities of education systems; (b) counselling services are aided in terms of infrastructure, managerial support, and stakeholder collaboration; and (c) counsellors continuously engage in self-improvement practices around theoretical and practical development.

\section{References}

Aladag, M., \& Bektas, D.Y. (2009). Examining individual counseling practicum in a Turkish undergraduate counseling program. Eğitim Araştırmalart-Eurasian Journal of Educational Research, 37, 53-70.

Aladăg, M., \& Kemer, G. (2016). Clinical supervision: An emerging counseling specialty in Turkey. The Clinical Supervisor, 35, 175-191. doi: 10.1080/07325223.2016.1223775

American Counselling Association. (2010). Consensus Definition of Counselling. Retrieved from http://www.counseling.org/ knowledge-center/20-20-a-vision-for-the-future-of-counseling/consensus-definition-of-counseling\#sthash.xVsS6hUu.dpuf

Arslan, Ü., \& Sommers-Flanagan, J. (2018). The new stage of the Turkish counseling system: Explosive growth (2000 to the present). Journal of Multicultural Counseling and Development, 46, 115-128. doi: 10.1002/jmcd.12096

Bemak, F., \& Chung, R.C.-Y. (2011). Applications in social justice counselor training: Classroom without walls. The Journal of Humanistic Counseling, 50, 204-219. doi: 10.1002/j.2161-1939.2011.tb00119.x

Boy, A.V., \& Pine, G. (1990). A person-centred foundation for counselling and psychotherapy. Springfield, Illinois: Charles C. Thomas Publisher. 
Casey-Cannon, S. (2008). The role of ethnic identity in the practice of school counseling. In H.L.K. Coleman \& C.J. Yeh (Eds.), Handbook of school counseling (pp. 127-134). New York, NY: Routledge.

Chang, C., Crethar, H., \& Ratts, M. (2010). Social justice: A national imperative for counselor education and supervision. Counselor Education and Supervision, 50, 82-87. doi: 10.1002/j.1556-6978.2010.tb00110.x

Coleman, H.L., \& Yeh, C. (2008). Handbook of school counseling. New York, NY: Routledge.

Coles, A., \& McGrath, J. (2010). Your education research project handbook. Essex, UK: Pearson Education.

Creswell, J.W., Plano Clark, V.L., Gutmann, M., \& Hanson, W. (2003). Advanced mixed methods research designs. In A. Tashakkori \& C. Teddlie (Eds.), Handbook of mixed methods in social and behavioral research (pp. 209-240). Thousand Oaks, CA: Sage.

Dahir, C.A. (2004). Supporting a nation of learners: The role of school counseling in educational reform. Journal of Counseling \& Development, 82, 344-353. doi: 10.1002/j.1556-6678.2004.tb00320.x

Dahir, C.A., Burnham, J.J., Stone, C.B., \& Cobb, N. (2010). Principals as partners: Counselors as collaborators. NASSP Bulletin, 94, 286-305. doi: 10.1177/0192636511399899

Denzin, N.K., \& Lincoln, Y.S. (2005). The SAGE handbook of qualitative research (3rd ed.). Thousand Oaks, CA: Sage.

Dogan, S. (2000). The historical development of counseling in Turkey. International Journal for the Advancement of Counselling, 22, 57-67. doi: 10.1023/A:1005474126819

Dollarhide, C.T., \& Saginak, K.A. (2012). Comprehensive school counseling programs. Upper Saddle River, NJ: Pearson.

Ender, Z., Saricali, M., Satici, S.A., \& Eraslan-Capan, B. (2018). Is mindful awareness effective on hope, burnout and selfefficacy regarding school counsellors in Turkey?. British Journal of Guidance \& Counselling, 1-16. doi: 10.1080/03069885. 2018.1458072

Fassinger, R.E., Buki, L.P., \& Shullman, S.L. (2017). Leadership in counseling psychology: Introduction to the special Issue. The Counseling Psychologist, 45, 742-751. doi: 10.1177/0011000017729755

Gonzalez, I.A. (2012). An examination of the relationship between practicing urban school counselors' colorblind racial ideology and social justice factors such as supports, barriers, self-efficacy and outcome expectations, and social justice interest and commitment (Unpublished doctoral dissertation). University of Maryland, College Park, MD.

Green, A., \& Keys, S. (2001). Expanding the developmental school counseling paradigm: Meeting the needs of 21st century student. Professional School Counseling, 5, 84-95.

Gysbers, N.C. (2001). School guidance and counseling in the 21st century: Remember the past into the future. Professional School Counseling, 5, 96-106.

Gysbers, N.C. (2002). So far, so good: Now what? The Counselling Psychologist, 30, 757-762. doi: 10.1177/0011000002305006

Hannon, M.D. (2016). Professional development needs of urban school counselors: A review of the literature. The Journal of Counselor Preparation and Supervision, 8, 139-154. doi: 10.7729/82.1171

Hansen, J.T. (2017). Psychological suffering as message or malady: Ideological and cultural contributions of humanism. The Journal of Humanistic Counseling, 56, 2-17. doi: 10.1002/johc.12041

Hatunoglu, A. (2017). Turkish school counselors and counselor educators' perceptions about multicultural counseling. International Journal for the Advancement of Counselling, 39, 1-13. doi: 10.1007/s10447-016-9278-3

Hill, C.E., Thompson, B.J., \& Williams, E.N. (1997). A guide to conducting consensual qualitative research. The Counseling Psychologist, 25, 517-572. doi: 10.1177/0011000097254001

Johnson, G., Nelson, J., \& Henriksen, R.C. (2011). Experiences of implementing a comprehensive guidance and counseling program at the elementary level. Journal of Professional Counseling, Practice, Theory, \& Research, 38, 18-32.

Kagnici, D.Y. (2014). Reflections of a multicultural counseling course: A qualitative study with counseling students and counselors. Kuram ve Uygulamada Eğitim Bilimleri, 14, 53-62. doi: 10.12738/estp.2014.1.1965

Keklik, İ. (2010). Psikolojik danışma alanının hak savunuculuğu bağlamında birey ötesi sorumlulukları [Advocacy: Responbilities of the fdeli of counseling beyond the individual client]. Türk Psikolojik Danışma ve Rehberlik Dergisi, 33, 89-99.

Korkut, F. (2007). Counselor education, program accreditation and counselor credentialing in Turkey. International Journal for the Advancement of Counselling, 29, 11-20. doi: 10.1007/s10447-006-9021-6

Kottler, J.A., \& Sheppard, D.S. (2008). Introduction to counseling: Voices from the field. Boston, MA: Thomson Higher Education.

McMahon, H.G., Mason, E.C.M., \& Paisley, P.O. (2009). School counselor educators as educational leaders promoting systemic change. Professional School Counseling, 13, 116-124. doi: 0.1177/2156759X0901300207

Ministry of National Education. (2001). Republic of Turkey Ministry of National Education, Guidance and Psychological Counselling Services Regulation. Retrieved from http://mevzuat.meb.gov.tr/html/68.html

Mocan-Aydin, G. (2000). Western models of counseling and psychotherapy within Turkey: Crossing cultural boundaries. The Counseling Psychologist, 28, 281-298. doi: 10.1177/0011000000282007

Moradi, B., \& Grzanka, P.R. (2017). Using intersectionality responsibly: Toward critical epistemology, structural analysis, and social justice activism. Journal of Counseling Psychology, 64, 500-513. doi: 10.1037/cou0000203

Natividad, L.D. (2010). The impact of conflicting perceptions on the role and function of high school guidance counselors (Unpublished doctoral dissertation). California State University, CA. 
Öner, N. (1994). A guidance and counseling model for Türkiye. In N. Öner \& G. Yildirim (Eds.), Üniversite seviyesinde rehberlik ve mesleğe yöneltme sempozyumu bildirileri (pp. 37-44). Istanbul, Turkey: Bogaziçi University Press.

Paisley, P.O., \& McMahon, G. (2001). School counseling for the 21st century: Challenges and opportunities. Professional School Counseling, 5, 106-115.

Perusse, R., \& Goodnough, G.E. (2005). Elementary and secondary school counselors' perceptions of graduate preparation programs: A national study. Counselor Education and Supervision, 45, 109-118. doi: 10.1002/j.1556-6978.2005.tb00134.x Ravi, M. (2010). Counselling: What, why and how. New Delhi: Viva Books.

Sakız, H., Sarıcalı, M., \& Türküm, A.S. (2017). Does disability matter in counselling? Views of counsellors with visual disabilities and their clients. British Journal of Guidance \& Counselling, 1-14. doi: 10.1080/03069885.2017.1393496

Sakız, H., Woods, C., Sart, H., Erşahin, Z., Aftab, R., Koç, N., \& Sarıçam, H. (2015). The route to 'inclusive counselling': Counsellors' perceptions of disability inclusion in Turkey. International Journal of Inclusive Education, 19, 250-269. doi: $10.1080 / 13603116.2014 .929186$

Sink, C.A. (2009). School counselors as accountability leaders: Another call for action. Professional School Counseling, 13, 68-74. doi: 10.5330/PSC.n.2010-13.68

Slaten, C.D., \& Baskin, T.W. (2014). Contextual school counseling: A framework for training with implications for curriculum, supervision, practice, and future research. The Counseling Psychologist, 42, 97-123. doi: 10.1177/ 0011000012473952

Stockton, R., \& Güneri, O.Y. (2011). Counseling in Turkey: An evolving field. Journal of Counseling \& Development, 89, 98-104. doi: 10.1002/j.1556-6678.2011.tb00065.x

Stone-Johnson, C. (2015). Counselors as policy actors: Challenges to systemic involvement in college and career readiness policy in secondary schools. American Secondary Education, 43, 27-43.

White, S.W., \& Kelly, F.D. (2010). The school counselor's role in school dropout prevention. Journal of Counseling \& Development, 88, 227-235. doi: 10.1002/j.1556-6678.2010.tb00014.x

Whiston, S.C., Tai, W.L., Rahardja, D., \& Eder, K. (2011). School counseling outcome: A meta-analytic examination of interventions. Journal of Counseling \& Development, 89, 37-55. doi: 10.1002/j.1556-6678.2011.tb00059.x

Yeşilyaprak, B. (2009). Türkiye'de psikolojik danışma ve rehberlik alanının geleceği: Yeni açlımlar ve öngörüler [The development oft he field of psychological counseling in Turkey: Recent advances and future prospects]. Ankara Üniversitesi Eğitim Bilimleri Fakültesi Dergisi, 42, 193-213.

Cite this article: Sakız H and Sarıçalı M (2019). Paradigmatic Challenges in School Counselling: Correlates and Reflections on Practice. Journal of Psychologists and Counsellors in Schools 29, 69-81. https://doi.org/10.1017/jgc.2018.23 